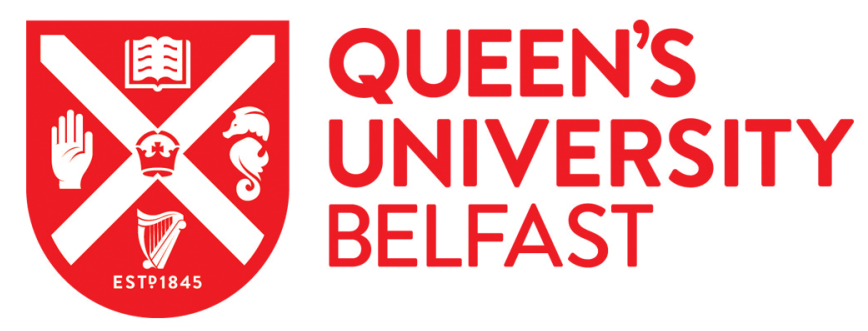

\title{
Interventions to improve antimicrobial stewardship for older people in care homes: a systematic review
}

Nguyen, H. Q., Tunney, M. M., \& Hughes, C. M. (2019). Interventions to improve antimicrobial stewardship for older people in care homes: a systematic review. Drugs \& Aging, 36(4), 355-369 .

https://doi.org/10.1007/s40266-019-00637-0

\section{Published in:}

Drugs \& Aging

\section{Document Version:}

Peer reviewed version

Queen's University Belfast - Research Portal:

Link to publication record in Queen's University Belfast Research Portal

Publisher rights

(c) 2019 Springer. This work is made available online in accordance with the publisher's policies. Please refer to any applicable terms of use of the publisher.

\section{General rights}

Copyright for the publications made accessible via the Queen's University Belfast Research Portal is retained by the author(s) and / or other copyright owners and it is a condition of accessing these publications that users recognise and abide by the legal requirements associated with these rights.

Take down policy

The Research Portal is Queen's institutional repository that provides access to Queen's research output. Every effort has been made to ensure that content in the Research Portal does not infringe any person's rights, or applicable UK laws. If you discover content in the Research Portal that you believe breaches copyright or violates any law, please contact openaccess@qub.ac.uk. 


\title{
Interventions to improve antimicrobial stewardship for older people in care homes: a systematic review
}

Running heading: Interventions to improve antimicrobial stewardship for older people in care homes

\author{
Hoa Q. Nguyen', Michael M. Tunney ${ }^{1}$, Carmel M. Hughes ${ }^{1}$ \\ ${ }^{1}$ School of Pharmacy, Medical Biology Centre, Queen's University Belfast, 97 Lisburn \\ Road, Belfast BT9 7BL, Northern Ireland, UK
}

Corresponding author:

Carmel M. Hughes

c.hughes@qub.ac.uk

Phone: +44 (0)28 90972147

Acknowledgements The authors would like to thank Ms. Angela Thompson (Queen's University Belfast) for her assistance with developing the search strategy and Dr. Audrey Rankin (Queen's University Belfast) for her advice on the content of data extraction sheets.

Compliance with ethical standards As this was a systematic review, ethical approval to conduct the study was not required.

Conflicts of interest Hoa Nguyen, Michael Tunney and Carmel Hughes have no conflicts of interest to declare.

Funding Hoa Nguyen is supported by a $\mathrm{PhD}$ Research Scholarship from the Vietnam International Education Cooperation Development in Vietnam. The funder played no role in the design, analysis or conduct of the study.

\begin{abstract}
Background Inappropriate antimicrobial prescribing has been reported in care homes. This may result in serious adverse drug events, Clostridium difficile colonisation and the development of antimicrobial resistance amongst care home residents. Interventions to improve antibiotic prescribing in nursing homes have been reported through clinical trials, but whether antifungal and antiviral prescribing and residential homes have been taken into account, or how outcomes were measured and reported in such interventions remains unclear. Objectives The aims were to evaluate the effect of interventions to improve antimicrobial stewardship in care homes and to report outcomes used in these trials.

Methods Eleven electronic databases and 5 trial registries were searched for studies published until November $30^{\text {th }}$ 2018. Inclusion criteria for the review were randomised controlled trials, targeting care home residents and healthcare professionals, providing interventions to improve antimicrobial prescribing compared to usual care or other interventions. The
\end{abstract}


Cochrane tools for assessing risk of bias were used for quality assessment. A narrative approach was performed due to heterogeneity across the studies.

Results Five studies met the inclusion criteria. The studies varied in terms of types of infection, key targets, delivery of interventions and reported outcomes. Twenty-seven outcomes were reported across the studies, with seven not pre-specified in the methods. The interventions had little impact on adherence to guidelines and prevalence of antimicrobial prescribing; they appeared to decrease total antimicrobial consumption but were unlikely to have affected overall hospital admissions and mortality. The overall quality of evidence was low due to high risk of bias across the studies.

Conclusion The interventions had limited effect on improving antimicrobial prescribing but did not appear to cause harm to care home residents. Low quality of evidence and heterogeneity in outcome measurement suggest the need for future well-designed studies and development of a core outcome set to best evaluate the effectiveness of antimicrobial stewardship in care homes.

\section{Key points}

- Older people in care homes are commonly prescribed antimicrobials for infection, which may lead to serious side effects, Clostridium difficile infection and antimicrobial resistance.

- Interventions had modest effects on antimicrobial prescribing but seemed to be safe for care home residents.

- A core outcome set should be developed for future interventions aimed at improving antimicrobial prescribing in care homes. 


\section{Background}

The population of older people in the world is growing significantly. According to a recent United Nations report, there was a substantial increase of $48 \%$ in the number of people aged 60 or over between 2000 and 2015, and this number has been predicted to reach 1.4 billion in 2030 [1]. As part of the response to this change in population dynamics, it is recommended that governments improve long-term care systems, including care homes, to meet the increasing needs of people at advanced age and maintain their well-being [1].

Care homes or long-term care facilities, consisting of nursing homes (providing nursing care) and residential homes (without nursing care) provide services and support for older people, especially those who are very frail or dependent on other care services in their everyday life. The prevalence of antimicrobial prescribing in such facilities varies among countries $[2,3]$ and high rates of inappropriate prescribing in terms of dosage, treatment duration, the decision to initiate or withhold antimicrobials, and regimens selected have been reported [49]. Furthermore, residents in care homes tend to receive higher numbers of antibiotic prescriptions for urinary tract infections (UTIs) than those not in care homes [10]. Inappropriate antimicrobial prescribing may potentially lead to serious adverse drug events, Clostridium difficile infection [11,12] with more frequent antibiotic use linked to the development of resistant pathogens [13]. Antibiotic-resistant pathogens are deemed to complicate treatment, reduce quality of life and increase mortality worldwide [14]. Therefore, approaches to reduce inappropriate antimicrobial prescribing are required to be implemented in long-term care facilities [15]. Antimicrobial stewardship is defined as an intervention to enhance the appropriateness of antimicrobial prescribing in order to optimise treatment and decrease the likelihood that antimicrobial resistance will develop [16,17]. Antimicrobial stewardship strategies have been implemented in acute care settings i.e. hospitals, but there have been calls to extend this to care homes [17-19].

A number of interventions, using various approaches to improve antimicrobial prescribing in long-term care facilities, have been undertaken and reported through clinical trials. The overall effect of these interventions has been described in the literature [20,21], but whether antimicrobial stewardship was implemented in residential homes (as opposed to homes with nursing care) or explored prescribing of other antimicrobials such as antivirals and antifungals was not reported. Moreover, how outcomes were measured and reported in antimicrobial stewardship interventions in long-term care facilities remains unclear. There has been concern about inconsistencies in reported outcomes in general that has impeded systematic reviewers in collating and combining findings [22]. Furthermore, substantial heterogeneity was reported for 372 outcomes in 47 trials of medication reviews in older patients, with insufficient evaluation of some important outcomes such as adverse events and patient reported outcomes across the studies [23]. Therefore, the aim of this systematic review was to analyse and evaluate the results of randomised controlled trials (RCTs) of interventions to improve antimicrobial stewardship for older people in care homes. We also sought to identify outcomes that had been used in these trials and how these had been reported. 


\section{Methods}

This systematic review was conducted in accordance with the Preferred Reporting Items for Systematic Reviews and Meta-Analyses (PRISMA) [24]. The protocol of the review was registered in the International Prospective Register of Systematic Reviews (PROSPERO) registry with the registration code CRD42017070116 [25].

\subsection{Eligibility Criteria}

All RCTs and cluster-RCTs (c-RCTs) were included in this study. Non-English publications were excluded from the review. Participants and settings that were eligible consisted of:

- Residents aged 65 years or over living in care homes. We used 65 years and over to define 'older people' as this has been considered as the conventional retirement age $[1,26]$. We accepted studies where the mean age of care home residents in each study arm was 65 or greater.

- Healthcare staff working in care homes or associated with care homes. This includes care home managers, care assistants, community nurses, general practitioners (GPs) and pharmacists who are responsible for specific care homes.

- Care homes. In the United Kingdom (UK), care homes include homes providing 24-hour care with nurses (nursing homes) or without nurses (residential homes) or both. In the United States of America (USA), care homes are defined as long-term care facilities which are divided into skilled-nursing facilities and assisted-living facilities. In Australia, care homes are referred to as aged-care facilities providing either high-level or low-level care, depending on the needs of residents.

We included any interventions which aimed to enhance antimicrobial stewardship in care homes compared to usual care or other interventions. Interventions were unifaceted or multifaceted (including guideline delivery, training courses, and educational material) to improve antimicrobial prescribing and aimed at healthcare professionals associated with care homes and/or relatives of care home residents. Interventions that focussed on cost analysis, medication errors or infection prevention were excluded. Usual care was defined as normal daily care where there was no attempt to deliberately affect antimicrobial prescribing.

Effectiveness of interventions were evaluated by a series of outcomes, which had been decided by the project team after having referred to a Cochrane review on interventions to improve antimicrobial prescribing in hospital settings [27]. The primary outcomes of the review were adherence to recommended antimicrobial guidelines, prevalence of antimicrobial prescribing (the proportion of care home residents prescribed antimicrobials), duration of antimicrobial treatment (the number of days that residents received antimicrobial therapy), and total antimicrobial consumption (defined daily doses (DDDs)/1000 resident-days). The secondary outcomes were hospital admissions and mortality. However, we also presented other reported outcomes in included studies that were not related to the review outcomes, in 
order to provide an overview of the range of outcomes used in antimicrobial stewardship studies.

\subsection{Identification of Studies}

Relevant articles published until November $30^{\text {th }} 2018$ were searched in eleven electronic databases: Ovid Medline, Embase, CINAHL Plus, SCOPUS, Web of Science, International Pharmaceutical Abstracts, Cochrane Central Register of Controlled Trials (CENTRAL), Database of Abstracts of Reviews of Effects, Health Technology Assessment Database, Open Grey, and Grey Literature Report. In addition, five clinical trial registries (ClinicalTrials.gov, ISRCTN registry, International Clinical Trials Registry Platform, EU Clinical Trials Register, UK Clinical Trials Gateway) were searched to identify relevant protocols and studies. A search strategy was firstly developed in Ovid Medline, having consulted with a subject librarian and was adapted for other databases and trial registries. Search terms are outlined in the search strategies in Online Resource 1 [see the electronic supplementary material (ESM)]. The reference lists of included articles were also searched to identify relevant studies.

After removal of duplicates, two review authors ( $\mathrm{HN}$, and either $\mathrm{MT}$ or $\mathrm{CH})$ independently screened all titles and abstracts of retrieved articles to identify potential studies. The authors also independently reviewed the full text articles and selected eligible studies that met all inclusion criteria. Reasons for exclusion were noted and disagreement was resolved by discussion.

\subsection{Risk of Bias}

Two review authors (HN, and either MT or $\mathrm{CH}$ ) independently assessed the methodological quality of included articles using The Cochrane Collaboration's Tool for Assessing Risk of Bias [28] and Risk of Bias Criteria for EPOC Reviews [29] without blinding to authors' names, institutions and journals of publication. The quality of studies was evaluated using the following criteria: random sequence generation, allocation concealment, blinding of participants and personnel, blinding of outcome assessment, incomplete outcome data, selective reporting, similarity of baseline outcomes, similarity of baseline characteristics, contamination protection, and other sources of bias (recruitment after randomisation, clustering effect not considered, inappropriate pre-randomization administration of an intervention, 'null bias' issues, inappropriate influence of funders, fraud). Any discrepancies of assessment between the authors were resolved by discussion and consultation with a third author.

\subsection{Data extraction and analysis}

Two review authors $(\mathrm{HN}$, and either $\mathrm{MT}$ or $\mathrm{CH})$ independently performed data extraction from included articles using data extraction sheets, including information on: study design (RCT or c-RCT), participants, setting, methods (unit of allocation, unit of analysis, study 
power, risk of bias assessment), type of intervention (components and functions), outcomes and results. Any discrepancies between the authors were resolved through discussion. Any remaining disagreement or uncertainty was resolved by consensus through discussion with another review author.

Due to heterogeneity of infections, study designs, and reported outcomes across the included studies, meta-analysis was not possible. Therefore, we performed a narrative analysis using the extracted data.

\section{Results}

A total of 9045 records were retrieved from 11 electronic databases and five trial registries. After removal of non-English publication and duplicates, 5791 records were included in the abstract screening. Seventeen articles were fully assessed for eligibility, and five c-RCTs were included in the final analysis. Sixteen potentially suitable records were identified in the reference lists of the included studies but none of these abstracts met the eligibility criteria. The detailed process of screening and selecting papers is presented in Fig. 1. 


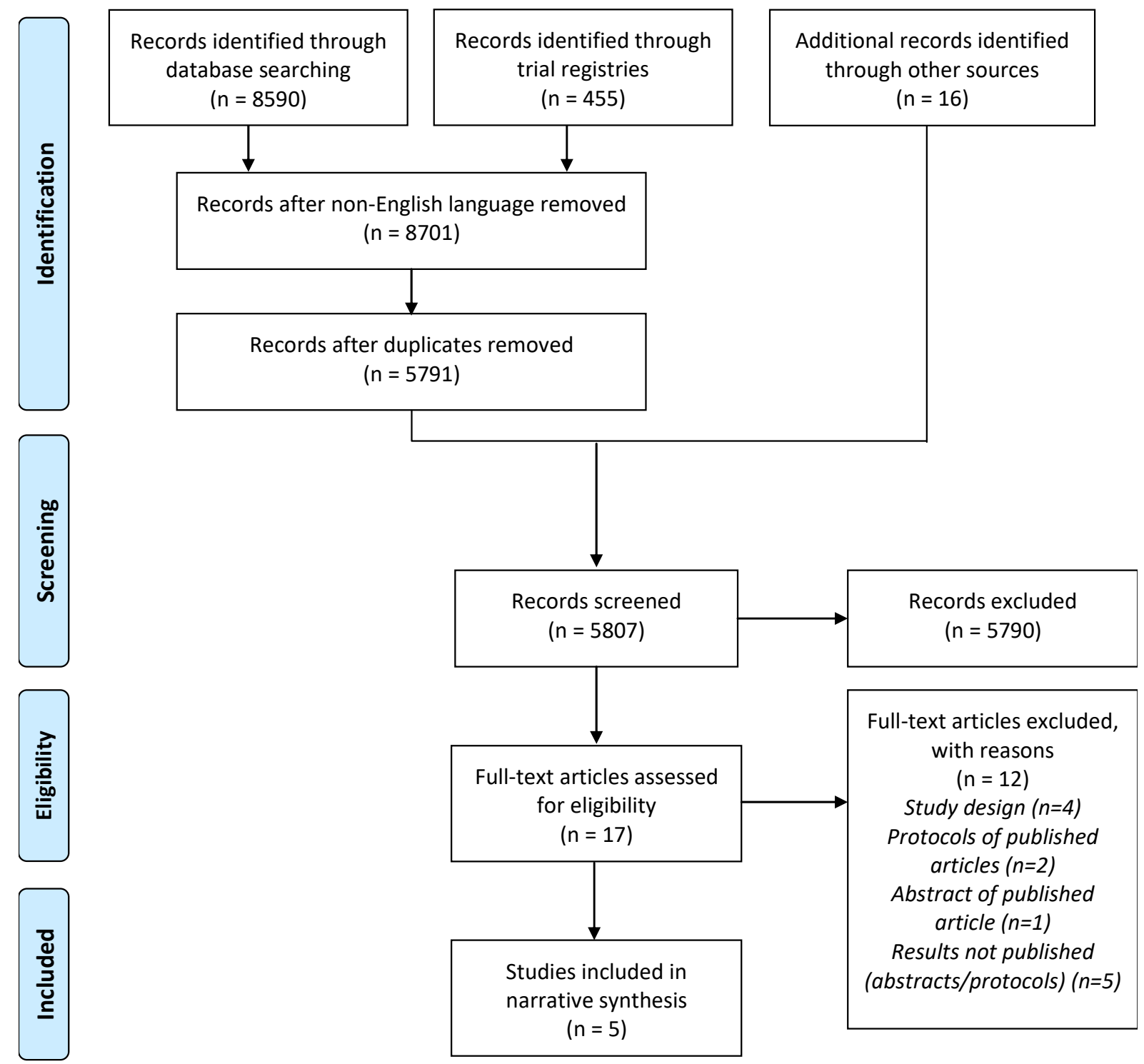

Fig. 1 Preferred Reporting Items for Systematic Reviews and Meta-Analyses (PRISMA) flow diagram of screening process and reasons for exclusion of studies

\subsection{Characteristics of studies}

The five c-RCTs varied greatly in terms of type of infection, targets for interventions, delivery of interventions, data analysis and reported outcomes (Table 1). The included studies, published between 2001 and 2014, were conducted in Europe and North America, consisting of one in the USA [30], one in both Canada and the USA [31], one in Canada [32], one in Sweden [33], and one in the UK [34].

The study settings were nursing homes in three studies [31,33,34], skilled nursing facilities in one study [30], and long-term care facilities in the remaining trial [32]. None of the five studies recruited residential homes. Two studies focused on all types of infections [32,34], whereas two focused on UTIs [31,33], and one focused on pneumonia [30]. However, data 
for all types of infections were also collected and reported briefly in the two studies targeting UTIs [31,33]. All five studies reported antibiotic-related data; no data relating to antivirals or antifungals were recorded. Study duration ranged from 15 to 20 months. In four studies, the comparator (control group) was usual care [31-34], whereas Naughton et al. compared a physician-targeted intervention with a physician and nursing staff-targeted intervention [30]. With regard to data analysis, the unit of analysis was the care home in two studies [30,31], care home residents in two studies [33,34], and physicians in the remaining studies [32].

\subsection{Characteristics of interventions}

The five included studies targeted different stakeholders to improve antimicrobial prescribing. Three studies developed interventions for both physicians and care home staff [30,31,33], whereas the other two were aimed at physicians only [32] or care home staff only, including home managers [34]. None of the included studies involved care home residents and their family members in the intervention development and delivery.

Interventions were multi-faceted and varied across the studies but shared similar approaches: developing diagnostic and treatment algorithms or guidelines, and delivering them to target stakeholders. Naughton et al. developed a treatment guideline for nursing home-acquired pneumonia from preceding research [35] and clinical experience, revised it through small group discussions with key physicians and nurse practitioners from general practices who were mainly responsible for recruited care homes, then delivered it to target physicians using laminated cards, or nursing staff in care homes via training sessions [30]. Loeb et al. generated treatment and diagnostic algorithms for management of UTIs from the literature, then designed a complex intervention consisting of individual meetings with key physicians responsible for each nursing home, case scenarios for nursing staff training, videotaped training sessions for staff who had not been able to attend case scenario sessions, and regular monitoring visits and audits in homes [31]. Monette et al. developed an antibiotic guide for common long-term care infections from published resources and local pharmacist assistance, and mailed the guide to target physicians, along with their last three-month antibiotic prescribing data on two separate occasions [32]. Pettersson et al. developed an intervention

from available guidelines for UTIs, focus group discussions with local physicians and nursing staff, and their previous work [33]. The intervention was then delivered to target physicians and nurses via training sessions, educational material, and feedback on prescribing. Fleet et al. introduced nursing home staff to an antimicrobial stewardship tool developed from the literature, along with a support pack which substituted for training sessions and regular visits [34]. The support pack included guidance for identifying common infections in older people and collecting specimens, information on antimicrobial resistance, and dedicated study contact information.

\subsection{Characteristics of reported outcomes}

A total of 27 outcomes were identified across the five studies (Table 2). The number of reported outcomes in each study ranged from one to nine. Nineteen outcomes were 
documented in the methodology sections of the papers, with 26 outcomes being reported in later sections of the papers. Of the 19 pre-specified outcomes, one (severity of pneumonia) was not reported [30]. There were seven reported outcomes that had not been pre-specified, consisting of two in the Loeb study [31], one in the Pettersson study [33], and four in the Fleet study [34]. Additionally, Loeb et al. pre-specified an outcome, 'admissions to hospital', but reported two related outcomes: 'the rate of all-cause admissions to hospital' and 'the rate of admission to hospital for sepsis of suspected urinary origin or of unknown origin' [31]. Protocols were identified for two of the five included studies [31,33], but only one study reported outcomes that had been pre-specified in the protocol [31].

\subsection{Effect of interventions on outcomes}

Due to marked heterogeneity between studies, outcomes reported could not be collated and combined in a quantitative analysis. Sixteen primary and secondary outcomes reported were related to the five outcomes identified for this systematic review (Table 2). No study examined the duration of antimicrobial treatment as an outcome.

\subsubsection{Adherence to recommended antimicrobial guidelines}

Two studies considered adherence to antimicrobial guidelines as the primary outcome $[30,32]$. Due to differences in the comparators between the studies, the effect of interventions on adherence to guidelines was inconclusive.

\section{Intervention vs usual care}

Monette et al. mailed antibiotic guides to physicians on two occasions and found a significant decrease in the proportion of non-adherent antibiotic prescriptions in the intervention group compared to the control group after the second occasion, whereas no significant difference between both groups was identified after the first intervention and during the three-month follow-up [32].

\section{Intervention vs intervention}

Naughton et al. compared two types of interventions: guideline training for physicians with or without assistance of nursing staff in care homes; no significant difference was found between the two groups in prescribing of both parenteral and oral antibiotics compliant with the pneumonia guideline [30].

\subsubsection{Prevalence of antimicrobial prescribing}

\section{Intervention vs usual care}

Three studies reported outcomes related to prevalence of antimicrobial prescribing in care homes [31,33,34]. With regard to total antimicrobial prescribing, no significant difference in the proportion of nursing home residents prescribed antimicrobials between intervention and control groups was identified in two studies [31,34]. However, Pettersson et al. found a 
significant decrease in the proportion of all infections treated with antibiotics in the intervention group compared to the control group [33].

In addition, two studies also reported prevalence of antimicrobial prescribing for particular infections [31,32]. Loeb et al. found that the rate of antimicrobial use and the proportion of total antimicrobials for suspected UTIs were significantly lower in the intervention group than in the control group, whereas proportions of antimicrobials for respiratory, skin and soft tissue, or other infections were not significantly different between groups [31]. Pettersson et al. also examined antibiotic prescribing for UTIs but found no significant difference in the proportion of quinolones or nitrofurantoin prescribed for women who were followed up in respect of this outcome in nursing homes between both groups [33].

\subsubsection{Total antimicrobial consumption}

\section{Intervention vs usual care}

Two studies reported total antimicrobial consumption by DDDs/1000 resident-days albeit for different infections [31,34]. Loeb et al. found a significant decrease in the rate of DDDs of prescribed antimicrobials for suspected UTIs in the intervention group compared to the control group [31]. Although there was baseline imbalance in total systemic antibiotic consumption for all types of infections between both groups, Fleet et al. found a significant reduction of DDDs/1000 resident-days in the intervention group in contrast with a significant increase in the control group [34].

\subsubsection{Overall hospital admissions}

\section{Intervention vs usual care}

Two studies reported that no significant difference was identified in hospital admissions irrespective of cause between the intervention and control groups [31,33].

\subsubsection{Overall mortality}

\section{Intervention vs usual care}

Overall mortality was reported in only one study. Loeb et al. found no significant difference in mortality for all causes between the intervention group and the control group [31].

\subsubsection{Other outcomes}

Intervention vs usual care

Pettersson et al. reported a significant decrease in the proportion of infections managed by physicians as 'wait and see' in the intervention group compared to the control group, but found no significant difference in the number of UTIs per resident between both groups [33]. Loeb et al. found no significant difference in the rate of urine cultures ordered and in the rate of hospitalisation for sepsis between both groups [31]. With regard to appropriateness of 
prescribing, Fleet et al. found a significant increase in the proportion of residents that fully met published criteria for the initiation of antibiotics in the intervention group compared to the control group [34]. Additionally, the mean point prevalence of antibiotics prescribed for prophylaxis was $2.46 \%$ at baseline and $2.18 \%$ post-intervention in the intervention group, compared with $4.44 \%$ at baseline and $5.10 \%$ post-intervention, in the control group. The authors also described compliance of nursing staff with an antimicrobial stewardship tool in the intervention group only and briefly reported no unexpected adverse effects of the tool [34].

\section{Pre-intervention vs post-intervention}

In the study by Naughton et al., antibiotic use at the time of diagnosis was compared between the pre-intervention and post-intervention groups regardless of the two intervention arms with no apparent significant difference [30]. There was no significant difference in hospitalisation rates and in 30-day mortality between before and after interventions [30]. 
Table 1 Characteristics of included studies and effect of interventions

\begin{tabular}{|c|c|c|c|c|c|c|c|}
\hline $\begin{array}{l}\text { Author } \\
\text { (country) }\end{array}$ & $\begin{array}{l}\text { Target } \\
\text { infection }\end{array}$ & $\begin{array}{l}\text { Study } \\
\text { settings } \\
\text { and } \\
\text { number of } \\
\text { facilities }\end{array}$ & $\begin{array}{c}\text { Total } \\
\text { number } \\
\text { of } \\
\text { residents } \\
\text { at } \\
\text { baseline }\end{array}$ & $\begin{array}{l}\text { Targets of } \\
\text { intervention }\end{array}$ & $\begin{array}{l}\text { Description of } \\
\text { intervention }\end{array}$ & $\begin{array}{l}\text { Study } \\
\text { duration }\end{array}$ & Measured outcomes \\
\hline \multirow[t]{4}{*}{$\begin{array}{l}\text { Naughton } \\
\text { et al. [30] } \\
\text { (USA) }\end{array}$} & \multirow[t]{4}{*}{$\begin{array}{l}\text { Nursing } \\
\text { home-- } \\
\text { acquired } \\
\text { pneumonia }\end{array}$} & \multirow[t]{4}{*}{$\begin{array}{l}10 \text { skilled } \\
\text { nursing } \\
\text { facilities }\end{array}$} & \multirow[t]{4}{*}{$N R$} & \multirow{4}{*}{$\begin{array}{l}\text { Physicians, } \\
\text { nurse } \\
\text { practitioners, } \\
\text { staff } \\
\text { registered } \\
\text { nurses, } \\
\text { licensed } \\
\text { practical } \\
\text { nurses }\end{array}$} & \multirow{4}{*}{$\begin{array}{l}\text { Physician-only } \\
\text { intervention group: } \\
\text { group discussions and } \\
\text { guideline dissemination } \\
\text { to physicians and nurse } \\
\text { practitioners } \\
\text { Multidisciplinary } \\
\text { intervention group: } \\
\text { similar to 'Physician- } \\
\text { only intervention' plus } \\
\text { training for nurses }\end{array}$} & \multirow[t]{4}{*}{18 months } & $\begin{array}{l}\text { Antibiotic use adherent to the guideline: no significant } \\
\text { difference in parenteral antibiotic use }(\mathrm{P}=0.13) \text { and in oral } \\
\text { antibiotic use }(\mathrm{P}=0.27) \text { adherent to the guideline between } \\
\text { two groups }\end{array}$ \\
\hline & & & & & & & $\begin{array}{l}\text { Antibiotic use at the time of diagnosis: no significant } \\
\text { difference in parenteral antibiotic use }(\mathrm{P}=0.63) \text { and in oral } \\
\text { antibiotic use }(\mathrm{P}=0.61) \text { between actual treatment and } \\
\text { expected treatment adherent to the guideline }\end{array}$ \\
\hline & & & & & & & $\begin{array}{l}\text { Hospitalization rates: no significant difference }(\mathrm{P}<0.34) \\
\text { between pre-intervention and post-intervention }\end{array}$ \\
\hline & & & & & & & $\begin{array}{l}\text { 30-day mortality: no significant difference in overall } 30 \text {-day } \\
\text { mortality ( } 23.9 \% \text { vs } 18.1 \%, \mathrm{P}=0.27) \text { between pre- } \\
\text { intervention and post-intervention }\end{array}$ \\
\hline \multirow[t]{3}{*}{$\begin{array}{l}\text { Loeb et al. } \\
{[31] \text { (USA }} \\
\text { and } \\
\text { Canada) }\end{array}$} & \multirow[t]{3}{*}{ UTIs } & \multirow{3}{*}{$\begin{array}{l}24 \text { nursing } \\
\text { homes } \\
\text { (20 } \\
\text { remained } \\
\text { during } \\
\text { follow-up) }\end{array}$} & \multirow[t]{3}{*}{$\mathrm{N}=4217$} & \multirow{3}{*}{$\begin{array}{l}\text { Registered } \\
\text { nurses, } \\
\text { nursing } \\
\text { assistants, } \\
\text { physicians }\end{array}$} & \multirow{3}{*}{$\begin{array}{l}\text { Intervention group: } \\
\text { meeting with and } \\
\text { algorithm dissemination } \\
\text { to physicians, real-time } \\
\text { and video training for } \\
\text { registered nurses and } \\
\text { nursing assistants, } \\
\text { regular visits and audits } \\
\text { Control group: Usual } \\
\text { care } \\
\text { (Note: baseline data } \\
\text { were not reported in } \\
\text { two groups) }\end{array}$} & \multirow[t]{3}{*}{19 months } & $\begin{array}{l}\text { Total antimicrobial use: no significant difference in the } \\
\text { number of courses of antimicrobials per } 1000 \text { resident days } \\
\text { between two groups ( } 3.52 \text { vs } 3.93 \text {, weighted mean } \\
\text { difference }-0.37,95 \% \text { CI }-1.17 \text { to } 0.44 \text { ) }\end{array}$ \\
\hline & & & & & & & $\begin{array}{l}\text { Rate of antimicrobial use for suspected UTIs: significantly } \\
\text { lower number of courses of antimicrobials per } 1000 \text { residen } \\
\text { days in the intervention group compared to the control } \\
\text { group ( } 1.17 \text { vs } 1.59 \text {, weighted mean difference }-0.49,95 \% \\
\text { CI }-0.93 \text { to }-0.06)\end{array}$ \\
\hline & & & & & & & $\begin{array}{l}\text { Proportion of total antimicrobials prescribed for suspected } \\
\text { UTI, compared to all antimicrobial courses: significantly } \\
\text { lower in the intervention group compared to the control } \\
\text { group ( } 28 \% \text { vs } 39 \% \text {, weighted mean difference }-9.6 \%, 95 \%\end{array}$ \\
\hline
\end{tabular}




\begin{tabular}{|c|c|c|c|c|c|c|c|}
\hline $\begin{array}{l}\text { Author } \\
\text { (country) }\end{array}$ & $\begin{array}{c}\text { Target } \\
\text { infection }\end{array}$ & $\begin{array}{l}\text { Study } \\
\text { settings } \\
\text { and } \\
\text { number of } \\
\text { facilities }\end{array}$ & $\begin{array}{c}\text { Total } \\
\text { number } \\
\text { of } \\
\text { residents } \\
\text { at } \\
\text { baseline }\end{array}$ & $\begin{array}{c}\text { Targets of } \\
\text { intervention }\end{array}$ & $\begin{array}{c}\text { Description of } \\
\text { intervention }\end{array}$ & $\begin{array}{c}\text { Study } \\
\text { duration }\end{array}$ & Measured outcomes \\
\hline & & & & & & & $\mathrm{CI}-16.9 \%$ to $-2.4 \%)$ \\
\hline & & & & & & & $\begin{array}{l}\text { Proportions of antimicrobials prescribed for respiratory, } \\
\text { skin and soft tissue, or other infections, compared to all } \\
\text { antimicrobial courses: no significant difference between two } \\
\text { groups (Figures: } N R \text { ) }\end{array}$ \\
\hline & & & & & & & $\begin{array}{l}\text { Defined daily doses of antimicrobials prescribed for } \\
\text { suspected UTIs: significantly lower rate of defined daily } \\
\text { doses per } 1000 \text { resident days in the intervention group ( } 6.9 \\
\text { vs } 10.9 \text {, weighted mean difference }-3.85,95 \% \text { CI }-7.37 \text { to - } \\
0.34 \text { ) }\end{array}$ \\
\hline & & & & & & & $\begin{array}{l}\text { Rate of all-cause admissions to hospital: no significant } \\
\text { difference in rate per } 1000 \text { resident days ( } 0.98 \text { vs } 0.81 \text {, } \\
\text { weighted mean difference } 0.17,95 \% \text { CI }-0.14 \text { to } 0.48 \text { ) } \\
\text { between two groups }\end{array}$ \\
\hline & & & & & & & $\begin{array}{l}\text { Rate of admission to hospital for sepsis of suspected urinary } \\
\text { origin or of unknown origin: no significant difference in rate } \\
\text { per } 1000 \text { resident days ( } 0.026 \text { vs } 0.018 \text {, weighted mean } \\
\text { difference } 0.008,95 \% \mathrm{CI}-0.025 \text { to } 0.039) \text { between two } \\
\text { groups }\end{array}$ \\
\hline & & & & & & & $\begin{array}{l}\text { Mortality: no significant difference in mortality per } 1000 \\
\text { resident days ( } 1.11 \text { vs } 1.09 \text {, weighted mean difference } 0.07 \text {, } \\
95 \% \mathrm{CI}-0.22 \text { to } 0.36) \text { between two groups }\end{array}$ \\
\hline & & & & & & & $\begin{array}{l}\text { Urine cultures obtained: no significant difference in rate per } \\
1000 \text { resident days ( } 2.03 \text { vs } 2.48 \text {, weighted mean difference } \\
-0.51,95 \% \mathrm{CI}-1.38 \text { to } 0.35) \text { between two groups }\end{array}$ \\
\hline
\end{tabular}




\begin{tabular}{|c|c|c|c|c|c|c|c|}
\hline $\begin{array}{c}\text { Author } \\
\text { (country) }\end{array}$ & $\begin{array}{c}\text { Target } \\
\text { infection }\end{array}$ & $\begin{array}{l}\text { Study } \\
\text { settings } \\
\text { and } \\
\text { number of } \\
\text { facilities }\end{array}$ & $\begin{array}{c}\text { Total } \\
\text { number } \\
\text { of } \\
\text { residents } \\
\text { at } \\
\text { baseline }\end{array}$ & $\begin{array}{l}\text { Targets of } \\
\text { intervention }\end{array}$ & $\begin{array}{c}\text { Description of } \\
\text { intervention }\end{array}$ & $\begin{array}{c}\text { Study } \\
\text { duration }\end{array}$ & Measured outcomes \\
\hline $\begin{array}{l}\text { Monette } \\
\text { et al. [32] } \\
\text { (Canada) }\end{array}$ & $\begin{array}{l}\text { All types of } \\
\text { infections }\end{array}$ & $\begin{array}{l}10 \text { long- } \\
\text { term care } \\
\text { facilities } \\
\text { (8 } \\
\text { remained } \\
\text { during } \\
\text { follow-up) }\end{array}$ & $\mathrm{N}=2168$ & Physicians & $\begin{array}{l}\text { Intervention group: } \\
\text { dissemination of an } \\
\text { antibiotic guideline and } \\
\text { two 3-month antibiotic } \\
\text { prescribing reports to } \\
\text { physicians on two } \\
\text { occasions } \\
\text { Control group: Usual } \\
\text { care }\end{array}$ & 15 months & $\begin{array}{l}\text { Non-adherence to the recommendations of the antibiotic } \\
\text { guide: no significant difference after the first intervention } \\
\text { ( } 38.4 \% \text { vs } 52.8 \%, \mathrm{OR}=0.47,95 \% \mathrm{CI} 0.21 \text { to } 1.05) \text {; } \\
\text { significantly lower non-adherence in the intervention group } \\
\text { after the second intervention ( } 28.4 \% \text { vs } 49.6 \% \text { OR }=0.36 \text {, } \\
95 \% \text { CI } 0.18 \text { to } 0.73 \text { ); no significant difference after the } \\
\text { three-month follow-up ( } 23.3 \% \text { vs } 35.7 \%, \mathrm{OR}=0.48,95 \% \mathrm{CI} \\
0.23 \text { to } 1.02 \text { ) between two groups. }\end{array}$ \\
\hline \multirow[t]{5}{*}{$\begin{array}{l}\text { Pettersson } \\
\text { et al. [33] } \\
\text { (Sweden) }\end{array}$} & \multirow[t]{5}{*}{ UTIs } & \multirow{5}{*}{$\begin{array}{l}58 \text { nursing } \\
\text { homes } \\
\text { (46 } \\
\text { remained } \\
\text { during } \\
\text { follow-up) }\end{array}$} & \multirow[t]{5}{*}{$\mathrm{N}=2537$} & \multirow[t]{5}{*}{$\begin{array}{l}\text { Nurses and } \\
\text { physicians }\end{array}$} & \multirow{5}{*}{$\begin{array}{l}\text { Intervention group: } \\
\text { Real-time training for } \\
\text { nurses and physicians, } \\
\text { dissemination of } \\
\text { educational materials, } \\
\text { feedback on } \\
\text { performance } \\
\text { Control group: Usual } \\
\text { care }\end{array}$} & \multirow[t]{5}{*}{20 months } & $\begin{array}{l}\text { Proportion of women with lower UTI prescribed quinolones } \\
\text { in relation to all women with lower UTI: no significant } \\
\text { difference ( }-0.196 \text { vs }-0.224 \text {, absolute risk reduction } 0.028 \text {, } \\
95 \% \text { CI }-0.193 \text { to } 0.249) \text { between both groups }\end{array}$ \\
\hline & & & & & & & $\begin{array}{l}\text { Proportion of infections treated with an antibiotic: } \\
\text { significantly lower proportion in the intervention group } \\
\text { compared to the control ( }-0.076 \text { vs } 0.048 \text {, absolute risk } \\
\text { reduction }-0.124,95 \% \text { CI }-0.228 \text { to }-0.019)\end{array}$ \\
\hline & & & & & & & $\begin{array}{l}\text { Proportion of women with lower UTI prescribed } \\
\text { nitrofurantoin, in relation to all women with lower UTI: no } \\
\text { significant difference ( }-0.014 \text { vs } 0.063 \text {, absolute risk } \\
\text { reduction }-0.077,95 \% \mathrm{CI}-0.242 \text { to } 0.088 \text { ) between both } \\
\text { groups }\end{array}$ \\
\hline & & & & & & & $\begin{array}{l}\text { UTI per resident: no significant difference }(-0.031 \text { vs } \\
-0.070 \text {, absolute risk reduction } 0.038,95 \% \mathrm{CI}-0.013 \text { to } \\
0.089) \text { between both groups }\end{array}$ \\
\hline & & & & & & & $\begin{array}{l}\text { Physicians' "wait and see" for all infections: significantly } \\
\text { higher proportion of infections handled by physicians as } \\
\text { 'wait and see' in the intervention group compared to the }\end{array}$ \\
\hline
\end{tabular}




\begin{tabular}{|c|c|c|c|c|c|c|c|}
\hline $\begin{array}{l}\text { Author } \\
\text { (country) }\end{array}$ & $\begin{array}{c}\text { Target } \\
\text { infection }\end{array}$ & $\begin{array}{l}\text { Study } \\
\text { settings } \\
\text { and } \\
\text { number of } \\
\text { facilities }\end{array}$ & $\begin{array}{c}\text { Total } \\
\text { number } \\
\text { of } \\
\text { residents } \\
\text { at } \\
\text { baseline } \\
\end{array}$ & $\begin{array}{c}\text { Targets of } \\
\text { intervention }\end{array}$ & $\begin{array}{l}\text { Description of } \\
\text { intervention }\end{array}$ & $\begin{array}{c}\text { Study } \\
\text { duration }\end{array}$ & Measured outcomes \\
\hline & & & & & & & $\begin{array}{l}\text { control }(0.093 \text { vs }-0.051 \text {, absolute risk reduction } 0.143 \text {, } \\
95 \% \text { CI } 0.047 \text { to } 0.240)\end{array}$ \\
\hline & & & & & & & $\begin{array}{l}\text { Admissions to hospital: no significant difference between } \\
\text { baseline data and post-intervention data in the intervention } \\
\text { group }(0.025,95 \% \mathrm{CI}-0.011 \text { to } 0.060) \text { and in the control } \\
\text { group }(-0.024,95 \% \mathrm{CI}-0.056 \text { to } 0.008)\end{array}$ \\
\hline \multirow[t]{4}{*}{$\begin{array}{l}\text { Fleet et al. } \\
{[34](\mathrm{UK})}\end{array}$} & \multirow[t]{4}{*}{$\begin{array}{l}\text { All types of } \\
\text { infections }\end{array}$} & \multirow[t]{4}{*}{$\begin{array}{l}30 \text { nursing } \\
\text { homes }\end{array}$} & \multirow[t]{4}{*}{$N=1628$} & \multirow[t]{4}{*}{$\begin{array}{l}\text { Nursing staff } \\
\text { and managers }\end{array}$} & \multirow{4}{*}{$\begin{array}{l}\text { Intervention group: } \\
\text { dissemination of } \\
\text { 'Resident Antimicrobial } \\
\text { Management Plan' } \\
\text { (RAMP) antimicrobial } \\
\text { stewardship tool to } \\
\text { nursing staff and } \\
\text { managers with a } \\
\text { support pack including } \\
\text { guidance for common } \\
\text { infections in older } \\
\text { people, information on } \\
\text { antimicrobial } \\
\text { resistance, and } \\
\text { dedicated study contact } \\
\text { information } \\
\text { Control group: Usual } \\
\text { care }\end{array}$} & \multirow[t]{4}{*}{17 months } & $\begin{array}{l}\text { Mean point prevalence of systemic antibiotic prescribing for } \\
\text { the treatment of infection: no significant difference between } \\
\text { pre- and post-intervention in the intervention group }(6.46 \% \\
\text { vs } 6.52 \% \text {, estimated prevalence ratio } 1.01,95 \% \text { CI } 0.81 \text { to } \\
1.25, \mathrm{P}=0.94) \text { and in the control group }(5.27 \% \text { vs } 5.83 \% \text {, } \\
\text { estimated prevalence ratio } 1.11,95 \% \text { CI } 0.87 \text { to } 1.41 \text {, } \\
\mathrm{P}=0.4)\end{array}$ \\
\hline & & & & & & & $\begin{array}{l}\text { Total systemic antibiotic consumption (DDDs } / 1000 \\
\text { resident-days): significant reduction in the intervention } \\
\text { group }(4.9 \%, 95 \% \text { CI } 1.0 \% \text { to } 8.6 \%, \mathrm{P}=0.02) \text { compared to } \\
\text { significant increase in the control group }(5.1 \%, 95 \% \mathrm{CI} \\
0.2 \% \text { to } 10.2 \%, \mathrm{P}=0.04)\end{array}$ \\
\hline & & & & & & & $\begin{array}{l}\text { Appropriateness of prescribing: significantly increased } \\
\text { proportion of residents that fully met the 'McGeer criteria' } \\
\text { (estimated relative increase } 6.44, \mathrm{P}=0.004 \text { ) and the 'Loeb } \\
\text { minimum criteria' ( } \mathrm{P}=0.001 \text { ) in the intervention group } \\
\text { compared to the control group. }\end{array}$ \\
\hline & & & & & & & $\begin{array}{l}\text { Prevention of infection: the mean point prevalence of } \\
\text { antibiotic prescribing for prophylaxis in the intervention } \\
\text { group was } 2.46 \% \text { pre-intervention and } 2.18 \% \text { post- } \\
\text { intervention, compared with } 4.44 \% \text { pre-intervention and } \\
5.10 \% \text { post-intervention, in the control group. }\end{array}$ \\
\hline
\end{tabular}




\begin{tabular}{|c|c|c|c|c|c|c|c|}
\hline $\begin{array}{l}\text { Author } \\
\text { (country) }\end{array}$ & $\begin{array}{c}\text { Target } \\
\text { infection }\end{array}$ & $\begin{array}{c}\text { Study } \\
\text { settings } \\
\text { and } \\
\text { number of } \\
\text { facilities }\end{array}$ & $\begin{array}{l}\text { Total } \\
\text { number } \\
\text { of } \\
\text { residents } \\
\text { at } \\
\text { baseline }\end{array}$ & $\begin{array}{c}\text { Targets of } \\
\text { intervention }\end{array}$ & $\begin{array}{c}\text { Description of } \\
\text { intervention }\end{array}$ & $\begin{array}{c}\text { Study } \\
\text { duration }\end{array}$ & Measured outcomes \\
\hline & & & & & & & $\begin{array}{l}\text { Compliance with RAMP (including Part A: Initiation of } \\
\text { Treatment, and Part B: Review of Treatment) in the } \\
\text { intervention group: } 46 \% \text { of RAMPs were fully complete for } \\
\text { Part A with a further } 40 \% \text { being } \geq 80 \% \text { complete; for Part B, } \\
31 \% \text { of RAMPs were fully complete with a further } 26 \% \\
\text { being } \geq 80 \% \text { complete }\end{array}$ \\
\hline & & & & & & & Adverse effects: no untoward consequences of RAMPs \\
\hline
\end{tabular}

NR Not reported, CI Confidence interval, OR Odds ratio, UTI unirary tract infection 
Table 2 Outcomes presented in included studies

\begin{tabular}{|c|c|c|}
\hline Authors & Outcomes pre-specified & Outcomes reported \\
\hline $\begin{array}{l}\text { Naughton } \\
\text { et al. } \\
(2001) \\
{[33]}\end{array}$ & $\begin{array}{l}\text { Primary: } \\
\text { - Antibiotic use at the time of diagnosis } \\
\text { - Antibiotic use consistent with the } \\
\text { guidelines } \\
\text { - Hospitalization } \\
\text { - 30-day mortality } \\
\text { - Severity of pneumonia }\end{array}$ & $\begin{array}{l}\text { - Antibiotic use at the time of diagnosis } \\
\text { (indicated treatment and actual treatment)* } \\
\text { - Antibiotic use consistent with the guidelines } \\
\text { (parenteral and oral) } \\
\text { - Hospitalization rates* } \\
\text { - 30-day mortality* }\end{array}$ \\
\hline $\begin{array}{l}\text { Loeb et al. } \\
(2005) \\
{[34]}\end{array}$ & $\begin{array}{l}\text { Primary: } \\
\text { - Rate of antimicrobials prescribed for } \\
\text { suspected UTIs } \\
\text { - Proportion of antimicrobials prescribed } \\
\text { for UTIs } \\
\text { - Total rate of antimicrobials prescribed } \\
\text { Secondary: } \\
\text { - Number of urine cultures ordered } \\
\text { - Admissions to hospital } \\
\text { - Deaths }\end{array}$ & $\begin{array}{l}\text { - Rate of antimicrobial use for suspected UTIs } \\
\text { - Proportion of antimicrobials prescribed for } \\
\text { suspected UTIs compared to all antimicrobial } \\
\text { courses } \\
\text { - Proportion of antimicrobials prescribed for } \\
\text { respiratory, skin and soft tissue, or other } \\
\text { infections compared to all antimicrobial courses } \\
\text { - Rate of defined daily doses of antimicrobials } \\
\text { prescribed for UTIs } \\
\text { - Total antimicrobial use } \\
\text { - Urine cultures obtained } \\
\text { - Rate of all-cause admissions to hospital } \\
\text { - Rate of admission to hospital for sepsis of } \\
\text { suspected urinary origin or of unknown origin } \\
\text { - Mortality }\end{array}$ \\
\hline $\begin{array}{l}\text { Monette et } \\
\text { al. } \\
(2007) \\
{[35]}\end{array}$ & $\begin{array}{l}\text { Primary: } \\
\text { - Non-adherence to the antibiotic guide } \\
\text { (antibiotic choice; dosage; adjustment for } \\
\text { creatinine clearance; duration) }\end{array}$ & $\begin{array}{l}\text { - Non-adherent antibiotic prescriptions } \\
\text { (antibiotic choice; dosage; adjustment for } \\
\text { creatinine clearance; duration) }\end{array}$ \\
\hline $\begin{array}{l}\text { Pettersson } \\
\text { et al. } \\
(2011) \\
{[36]}\end{array}$ & $\begin{array}{l}\text { Primary: } \\
\text { - Proportion of quinolones for lower UTI } \\
\text { in women } \\
\text { Secondary: } \\
\text { - Number of UTIs per resident } \\
\text { - Proportion of infections treated with } \\
\text { antibiotics for all infections } \\
\text { - Proportion of infections handled by } \\
\text { physicians as 'wait and see' for all } \\
\text { infections } \\
\text { - Proportion of nitrofurantoin for lower } \\
\text { UTI in women }\end{array}$ & $\begin{array}{l}\text { - Proportion of women with lower UTI } \\
\text { prescribed quinolones in relation to all women } \\
\text { with lower UTI } \\
\text { - UTI per resident } \\
\text { - Antibiotic prescriptions for all infections } \\
\text { - Proportion of infections marked physicians' } \\
\text { "wait and see" in relation to all infections } \\
\text { - Proportion of women with lower UTI } \\
\text { prescribed nitrofurantoin, in relation to all } \\
\text { women with lower UTI } \\
\text { - Adverse events of the intervention (admissions } \\
\text { to hospital) }\end{array}$ \\
\hline $\begin{array}{l}\text { Fleet et al. } \\
(2014) \\
{[37]}\end{array}$ & $\begin{array}{l}\text { Primary: } \\
\text { - Change in systemic antibiotic use for } \\
\text { treatment of infection (prevalence) } \\
\text { - Defined daily doses (DDDs)/1000 } \\
\text { residents/day (DRD) (total consumption) }\end{array}$ & $\begin{array}{l}\text { - Mean point prevalence of systemic antibiotic } \\
\text { prescribing for the treatment of infection } \\
\text { - Total systemic antibiotic consumption (DRD) } \\
\text { (over a } 12 \text { week period) } \\
\text { - Compliance with RAMP** } \\
\text { - Appropriateness of prescribing (McGeer } \\
\text { criteria; Loeb minimum criteria) } \\
\text { - Prevention of infection } \\
\text { - Adverse effects (untoward consequences of } \\
\text { RAMPs)** }\end{array}$ \\
\hline
\end{tabular}




\subsection{Quality assessment}

'Risk of bias' assessment of the included studies is presented in Online Resource 2 [see the ESM]. The 'risk of bias' summary across the studies is shown in Fig. 2 and Fig. 3. Overall, blinding of participants and personnel was the highest rated risk. Moreover, domains which were at high risk of bias in at least two studies included incomplete outcome data, selective reporting, similar baseline characteristics and similar baseline outcome measurements. At least one element of bias judged as high risk was detected in each study. One study was judged as high risk in the 'other bias' domain because the clustering effect had not been taken into account.

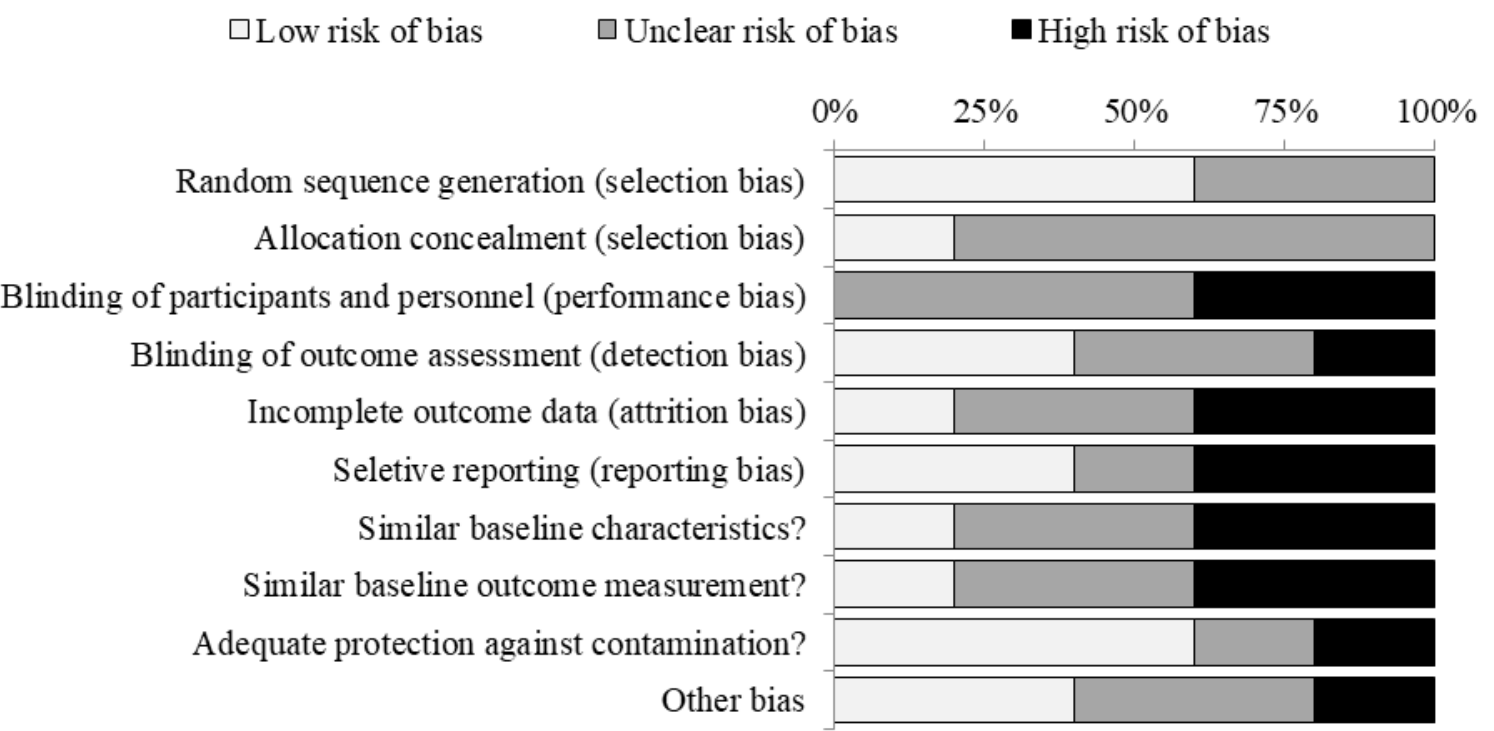

Fig. 2 Risk of bias: review authors' judgements about each risk of bias item presented as percentages across all included studies 


\begin{tabular}{|c|c|c|c|c|c|c|c|c|c|c|}
\hline & 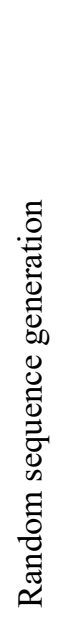 & 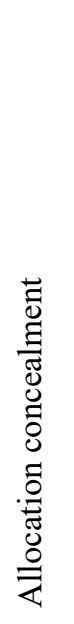 & 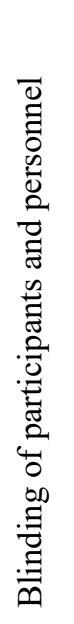 & 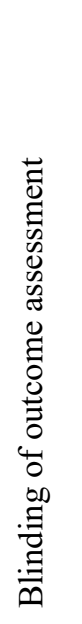 & 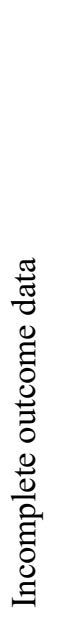 & 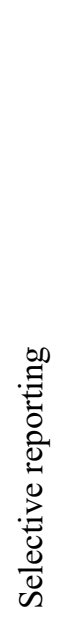 & 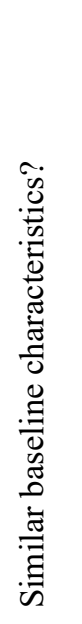 & 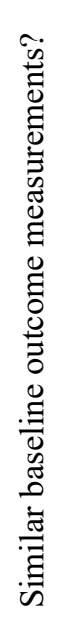 & 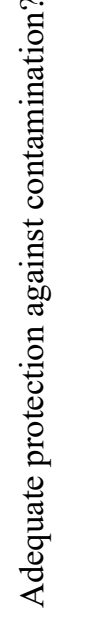 & 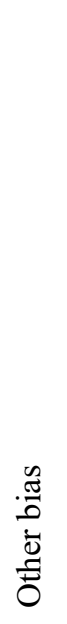 \\
\hline $\begin{array}{l}\text { Fleet et al. } \\
2014\end{array}$ & (?) & (?) & (?) & $(-)$ & $(?)$ & $(-)$ & $(-)$ & $(-)$ & (?) & (?) \\
\hline $\begin{array}{l}\text { Loeb et al. } \\
2005\end{array}$ & $(+)$ & $(+)$ & $(-)$ & $(+)$ & $(?)$ & $(+)$ & (?) & (?) & $(+)$ & $(+)$ \\
\hline $\begin{array}{c}\text { Monette et al. } \\
2007\end{array}$ & $(+)$ & (?) & $(-)$ & (?) & $(-)$ & $(+)$ & $(-)$ & $(-)$ & $(+)$ & $(-)$ \\
\hline $\begin{array}{l}\text { Naughton et al. } \\
2001\end{array}$ & (?) & (?) & (?) & (?) & $(+)$ & $(-)$ & (?) & (?) & $(+)$ & (?) \\
\hline $\begin{array}{l}\text { Pettersson et al. } \\
2011\end{array}$ & $(+)$ & (?) & (?) & $(+)$ & $(-)$ & (?) & $(+)$ & $(+)$ & $(-)$ & $(+)$ \\
\hline
\end{tabular}

$(+)$ : low risk of bias; (-): high risk of bias; (?): unclear risk of bias

Fig. 3 Risk of bias summary: review authors' judgements about each risk of bias item for each included study

\section{Discussion}

This systematic review highlights the effect of interventions and reported outcomes in cRCTs to improve antimicrobial stewardship in care homes. Although the findings were inconsistent across the studies, the interventions had modest effects on adherence to antimicrobial guidelines and prevalence of antimicrobial prescribing, were likely to improve antimicrobial consumption based on DDDs/ 1000 resident-days, but did not affect overall hospitalisation and mortality.

The quality of evidence from the included studies was undermined since several high risks of bias were detected that may have affected the final results. None of the studies were determined to be low risk in terms of blinding of participants and personnel. This is possibly due to the complex nature of the cluster trials where blinding is difficult to implement. However, this issue can be mitigated by selecting outcomes that are objective and not affected by non-blinded clusters [28]. Baseline balance should be sought in a c-RCT as it increases credibility, analytical power, and statistical precision [36]. Baseline imbalance in the studies potentially compromised final results and possibly downgraded the overall quality of evidence. Moreover, loss to follow-up was the main reason for incompleteness of outcome 
data which may have decreased the study power and influenced data interpretation. High risks of bias were also detected in the selective reporting domain. Outcomes that were not reported or reported without being pre-specified in the protocols or in the methodology also reduced the credibility and validity of the studies. This issue has been reported in several studies [37-39]; Smyth et al. found that the underlying reasons for this feature were related to poor research practice and constrained time for protocol writing [40].

The findings of the review were consistent with previous publications. An earlier systematic review to determine components of a successful intervention from RCTs on antibiotic prescribing in long-term care facilities found a modest effect from four included studies [20]. Another systematic review to assess the potential benefit of antibiotic stewardship programmes in nursing homes indicated an encouraging but limited effect based on the findings from 14 studies [21]. Previous systematic reviews focused solely on nursing homes and antibiotic prescribing; we also searched for intervention studies which were conducted in residential homes or which targeted antivirals and antifungals in care homes. No such studies, however, were identified. High levels of antimicrobial prescribing have also been reported in residential homes, which reinforces the need for antimicrobial stewardship in these facilities $[5,10]$. Bacterial infections account for the most common infections and have the most significant impact on care home residents [41]; nevertheless, viral and fungal infections have also been identified amongst residents of care homes [41-43]. Research has identified that development of resistance to antivirals and antifungals has occurred in common pathogens [44-46]. Although prescribing of antivirals and antifungals has been reported in care homes $[3,47]$, no study has evaluated their appropriateness. According to NICE, antimicrobial stewardship should focus not on only antibacterials but also antivirals, antifungals, and antiparasitics [17].

This review detected a total of 27 outcomes across the five studies which prevented any type of quantitative synthesis. This heterogeneity may be due to the fact that outcomes were selected according to characteristics of interventions and target infections which varied across the studies. It should be noted that none of these outcomes directly assessed antimicrobial resistance. One of the main aims of antimicrobial stewardship is to preserve the future use of antimicrobials, or to reduce antimicrobial resistance [16,17]. However, it is difficult to directly measure antimicrobial resistance, especially in community-based settings, due to the complexity of microbiological methods, variation of antimicrobial-resistant strains, and bias in interpretation $[48,49]$. Resistance rates are also possibly manipulated by other factors which are beyond the scope of antimicrobial stewardship, such as infection control practices [50]. In addition, it may take several years for trials testing the effectiveness of antimicrobial stewardship programmes to result in changes in antimicrobial resistance [49,51]. Antimicrobial consumption is a good surrogate outcome for antimicrobial resistance as the relationship between antimicrobial exposure and antimicrobial resistance has been wellestablished: a decrease in antimicrobial consumption is associated with a decrease in resistance [48,52]. WHO-assigned DDDs have been used widely to calculate antimicrobial consumption in a number of studies because this method has been standardised and its values allow international comparison [53]. However, total antimicrobial consumption expressed in DDDs/ 1000 residents-days should be interpreted carefully as it may not accurately reflect 
antimicrobial use. Neilly et al. found an increase in antimicrobial DDDs in contrast to a decrease in the mean number of prescriptions over the study period [54]. In addition, the DDD method inaccurately estimated days of therapy when the actual daily dose was not equal to the DDD, and this method was not recommended in situations where reduced doses were advocated e.g. renal impairment [55]. Evidence has shown that an increased number of antimicrobial courses is associated with resistance [56]; therefore, it is recommended that the DDD method should not be used in isolation but could be applied along with the number of antimicrobial courses to best evaluate antimicrobial use.

Besides antimicrobial consumption, other surrogate outcomes, such as duration of treatment and consumption of broad-spectrum antimicrobials, may be closely linked with antimicrobial resistance. Duration of antimicrobial treatment was the primary outcome selected for scrutiny in this review that was not reported in any of the studies. A previous systematic review indicated that the longer the period of antibiotic exposure experienced by a patient in the previous 12 months, the greater the likelihood of isolation of resistant bacteria from that patient in primary care [56]; in contrast, short duration of antibiotic treatment has been supported by a number of studies in order to reduce resistance [57-59]. Duration of treatment, or days of therapy, can be used to measure antimicrobial use regardless of changes in antimicrobial doses [55]. Indeed, days of therapy approach was one of six recommended metrics to assess antimicrobial stewardship interventions in acute-care settings according to an expert consensus [60]. Although duration of antimicrobial treatment may not be measured in some settings due to unavailability of patient-level data [53,61], this outcome should be considered in future research focusing on antimicrobial stewardship in care homes. In addition, consumption of broad-spectrum antimicrobials has been associated with accelerating antimicrobial resistance and Clostridium difficile colonisation $[49,62,63]$. High rates of broad-spectrum antimicrobials prescribed in long-term care facilities have been reported [2,3]; therefore, a metric for consumption of broad-spectrum antimicrobials should be considered to assess the impact of antimicrobial stewardship on antimicrobial resistance in care homes.

In addition to the aim of reducing resistance, antimicrobial stewardship should ensure that interventions cause no harm, such as drug adverse events, hospitalisation and mortality, or improve clinical outcomes [16,49]. Although this review found no significant change in rates of hospitalisation and mortality, two of the five included studies did not report these outcomes. It should also be noted that hospital admissions and mortality were secondary outcomes in the other two c-RCTs which had not been powered to detect any difference. Besides clinical outcomes, economic outcomes (e.g. antimicrobial costs) have also been suggested to evaluate the impact of antimicrobial stewardship programmes [49,51]. However, no such outcomes were reported in the included studies in this review.

To date, there is no consensus on what represents the best outcomes and how they are measured to assess the effectiveness of antimicrobial stewardship intervention, especially in care home settings. The number of outcomes reported in this review and the lack of guidelines to best evaluate antimicrobial stewardship in care homes suggests the need to generate a core outcome set for trials aimed at antimicrobial stewardship in these facilities. Since 2010, the Core Outcome Measures in Effectiveness Trials (COMET) Initiative has 
called for development and application of core outcome sets for clinical trials [64]. A core outcome set (COS) is defined as a standardised list of outcomes achieved by consensus that should be reported in all trials of a specific health area [65]. It stemmed from the proposal that evidence interpretation would be facilitated and outcome reporting bias would be reduced if all studies focusing on similar issues used the same set of standard outcomes [65]. A COS for antimicrobial stewardship interventions in care homes should have a short list of the most important outcomes that clearly aid in the interpretation of the effectiveness of the interventions.

One of the strengths of the review is the extensive searching in five trial registries, eleven electronic databases which included two grey literature resources, and all reference lists of the included studies. The search strategy was designed to identify as many potential articles as possible in each database. The review evaluated the effectiveness of c-RCTs which may provide more reliable evidence compared to non-randomised studies. The assessment of methodological quality used nine domains for c-RCTs to rigorously evaluate the included studies. Nevertheless, there are several limitations in the review. Inclusion of only English publications from the initial records may have led to exclusion of eligible studies in other languages. The paucity of c-RCTs and the inability of conducting meta-analysis weakened the quality of evidence.

\section{Conclusion}

This systematic review evaluated the results of interventions from c-RCTs to improve antimicrobial stewardship in care homes. The interventions had limited effect on improving antimicrobial prescribing and likely caused no harm to care home residents. However, the quality of evidence was low due to high risk of bias. These findings highlight the need for future well-designed studies aimed at antimicrobial stewardship in care homes that should minimise potential bias, especially blinding of participants, loss to follow-up, and baseline imbalance. Numerous and heterogeneous outcomes that were reported across the studies impeded data synthesis. This reinforces the need for a COS for trials to improve antimicrobial prescribing in care homes to reduce heterogeneity in outcome measurement and to best evaluate the effectiveness of antimicrobial stewardship.

\section{REFERENCES}

1. United Nations, Department of Economic and Social Affairs, Population Division. World Population Ageing. 2015. http://www.un.org/en/development/desa/population/publications/pdf/ageing/WPA2015 _Report.pdf. Accessed 31 Aug 2018.

2. McClean P, Hughes C, Tunney M, Goossens H, Jans B. Antimicrobial prescribing in European nursing homes. J Antimicrob Chemother. 2011;66(7):1609-16.

3. European Centre for Disease Prevention and Control. Point prevalence survey of 
healthcare-associated infections and antimicrobial use in European long-term care facilities. April-May 2013. Stockholm; 2014.

https:/ecdc.europa.eu/sites/portal/files/media/en/publications/Publications/healthcareassociated-infections-point-prevalence-survey-long-term-care-facilities-2013.pdf. Accessed 31 Aug 2018.

4. Stuart RL, Wilson J, Bellaard-Smith E, et al. Antibiotic use and misuse in residential aged care facilities. Intern Med J. 2012;42(10):1145-9.

5. McClean P, Tunney M, Gilpin D, Parsons C, Hughes C. Antimicrobial prescribing in residential homes. J Antimicrob Chemother. 2012;67(7):1781-90.

6. Van Buul LW, Van der Steen JT, Veenhuizen RB, et al. Antibiotic Use and Resistance in Long Term Care Facilities. J Am Med Dir Assoc. 2012;13(6):568.e1-568.e13. https://doi.org/10.1016/j.jamda.2012.04.004.

7. Van Buul LW, Veenhuizen RB, Achterberg WP, et al. Antibiotic prescribing in Dutch nursing homes: How appropriate is it? J Am Med Dir Assoc. 2015;16(3):229-37.

8. Lim CJ, Kong DC, Stuart RL. Reducing inappropriate antibiotic prescribing in the residential care setting: current perspectives. Clin Interv Aging. 2014;9:165-77.

9. Peron EP, Hirsch AA, Jury LA, Jump RL, Donskey CJ. Another Setting for Stewardship: High Rate of Unnecessary Antimicrobial Use in a Veterans Affairs Long-Term Care Facility. J Am Geriatr Soc. 2013;61(2):289-90.

10. Sundvall P-D, Stuart B, Davis M, Roderick P, Moore M. Antibiotic use in the care home setting: a retrospective cohort study analysing routine data. BMC Geriatr. 2015;15(1):71.

11. Corsonello A, Abbatecola AM, Fusco S, et al. The impact of drug interactions and polypharmacy on antimicrobial therapy in the elderly. Clin Microbiol Infect. 2015;21(1):20-6.

12. Fletcher KR, Cinalli M. Identification, Optimal Management, and Infection Control Measures for Clostridium difficile-Associated Disease in Long-Term Care. Geriatr Nurs (Minneap). 2007;28(3):171-81.

13. World Health Organization. Global action plan on antimicrobial resistance. 2015. http://www.wpro.who.int/entity/drug_resistance/resources/global_action_plan_eng.pdf . Accessed 31 Aug 2018.

14. World Health Organization. Antimicrobial resistance: global report on surveillance. 2014.

http://apps.who.int/iris/bitstream/10665/112642/1/9789241564748_eng.pdf?ua=1. Accessed 31 Aug 2018.

15. Smith PW, Bennett G, Bradley S, et al. SHEA/APIC Guideline: Infection Prevention and Control in the Long-Term Care Facility. Infect Control Hosp Epidemiol. 2008;29(9):785-814.

16. Fishman N. Policy Statement on Antimicrobial Stewardship by the Society for Healthcare Epidemiology of America (SHEA), the Infectious Diseases Society of 
America (IDSA), and the Pediatric Infectious Diseases Society (PIDS). Infect Control Hosp Epidemiol. 2012;33(04):322-7.

17. National Institute for Health and Care Excellence. Antimicrobial stewardship : systems and processes for effective antimicrobial medicine use, NICE guideline [NG15]. 2015. https://www.nice.org.uk/guidance/ng15/resources/antimicrobial-stewardship-systemsand-processes-for-effective-antimicrobial-medicine-use-1837273110469. Accessed 31 Aug 2018.

18. Rhee SM, Stone ND. Antimicrobial stewardship in long-term care facilities. Infect Dis Clin North Am. 2014;28(2):237-46.

19. Barlam TF, Cosgrove SE, Abbo LM, et al. Executive summary: Implementing an antibiotic stewardship program: Guidelines by the infectious diseases society of America and the society for healthcare epidemiology of America. Clin Infect Dis. 2016;62(10):1197-202.

20. Fleming A, Browne J, Byrne S. The Effect of Interventions to Reduce Potentially Inappropriate Antibiotic Prescribing in Long-Term Care Facilities: a Systematic Review of Randomised Controlled Trials. Drugs Aging. 2013;30(6):401-8.

21. Feldstein D, Sloane PD, Feltner C. Antibiotic Stewardship Programs in Nursing Homes: A Systematic Review. J Am Med Dir Assoc. 2018;19(2):110-6.

22. Clarke M, Williamson PR. Core outcome sets and systematic reviews. Syst Rev. 2016;5:11.

23. Beuscart JB, Pont LG, Thevelin S, et al. A systematic review of the outcomes reported in trials of medication review in older patients: the need for a core outcome set. Br J Clin Pharmacol. 2017;83(5):942-52.

24. Moher D, Liberati A, Tetzlaff J, et al. Preferred reporting items for systematic reviews and meta-analyses: The PRISMA statement. PLoS Med. 2009;6(7):e1000097. https://doi.org/10.1371/journal.pmed.1000097.

25. Nguyen $\mathrm{H}$, Hughes $\mathrm{C}$, Tunney M. Interventions to improve antimicrobial stewardship for older people in care homes. PROSPERO 2017 CRD42017070116; 2017. http://www.crd.york.ac.uk/PROSPERO/display_record.php?ID=CRD42017070116. Accessed 31 Aug 2018.

26. Rodrigues R, Huber M, Lamura G, (eds.). Facts and Figures on Healthy Ageing and Long-term Care. Vienna: European Centre for Social Welfare Policy and Research; 2012. https://www.euro.centre.org/downloads/detail/3059. Accessed 31 Aug 2018.

27. Davey P, Marwick C, Scott C, et al. Interventions to improve antibiotic prescribing practices for hospital inpatients. Cochrane database Syst Rev. 2017;(2):CD003543. https://doi.org/10.1002/14651858.CD003543.pub4.

28. Higgins J, Altman D, Sterne J. Chapter 8: Assessing risk of bias in included studies. In: Higgins JPT, Green S (editors). Cochrane Handb Syst Rev Interv. 2011. http://handbook-5-1.cochrane.org/. Accessed 31 Aug 2018.

29. Effective Practice and Organisation of Care (EPOC). Suggested risk of bias criteria for 
EPOC reviews. EPOC Resources for review authors. Oslo: Norwegian Knowledge Centre for the Health Services. 2016. http://epoc.cochrane.org/resources/epocresources-review-authors. Accessed 31 Aug 2018.

30. Naughton B, Mylotte J, Ramadan F, Karuza J, Priore R. Antibiotic Use, Hospital Admissions, and Mortality Before and After Implementing Guidelines for Nursing Home-Acquired Pneumonia. J Am Geriatr Soc. 2001;49(8):1020-4.

31. Loeb M, Brazil K, Lohfeld L, et al. Effect of a multifaceted intervention on number of antimicrobial prescriptions for suspected urinary tract infections in residents of nursing homes: Cluster randomised controlled trial. Br Med J. 2005;331(7518):669-72.

32. Monette J, Miller MA, Monette M, et al. Effect of an educational intervention on optimizing antibiotic prescribing in long-term care facilities. J Am Geriatr Soc. 2007;55(8):1231-5.

33. Pettersson E, Vernby Å, Mölstad S, Lundborg CS. Can a multifaceted educational intervention targeting both nurses and physicians change the prescribing of antibiotics to nursing home residents? A cluster randomized controlled trial. J Antimicrob Chemother. 2011;66(11):2659-66.

34. Fleet E, Rao GG, Patel B, et al. Impact of implementation of a novel antimicrobial stewardship tool on antibiotic use in nursing homes: A prospective cluster randomized control pilot study. J Antimicrob Chemother. 2014;69(8):2265-73.

35. Naughton B, Mylotte J. Treatment guideline for nursing home-acquired pneumonia based on community practice. J Am Geriatr Soc. 2000;48:82-88.

36. Ivers NM, Halperin IJ, Barnsley J, et al. Allocation techniques for balance at baseline in cluster randomized trials: a methodological review. Trials. 2012;13:1-9.

37. Jones CW, Keil LG, Holland WC, Caughey MC, Platts-Mills TF. Comparison of registered and published outcomes in randomized controlled trials: A systematic review. BMC Med. 2015;13:282.

38. Ioannidis JP, Caplan AL, Dal-Ré R. Outcome reporting bias in clinical trials: Why monitoring matters. BMJ. 2017;356:j408. https://doi.org/10.1136/bmj.j408.

39. Lancee M, Lemmens CMC, Kahn RS, Vinkers CH, Luykx JJ. Outcome reporting bias in randomized-controlled trials investigating antipsychotic drugs. Transl Psychiatry. 2017;7(9):e1232. https://dx.doi.org/10.1038/tp.2017.203.

40. Kirkham JJ, Dwan KM, Altman DG, et al. The impact of outcome reporting bias in randomised controlled trials on a cohort of systematic reviews. BMJ. 2010;340(7747):637-40.

41. Montoya A, Mody L. Common infections in nursing homes: a review of current issues and challenges. Aging health. 2011;7(6):889-99.

42. Flevari A, Theodorakopoulou M, Velegraki A, Armaganidis A, Dimopoulos G. Treatment of invasive candidiasis in the elderly: A review. Clin Interv Aging. 2013;8:1199-208. 
43. Lubeek SFK, van der Geer ER, van Gelder MMHJ, Koopmans RTCM, van de Kerkhof PCM, Gerritsen MJP. Current Dermatologic Care in Dutch Nursing Homes and Possible Improvements: A Nationwide Survey. J Am Med Dir Assoc. 2015;16(8):714.e1-714.e6. https://doi.org/10.1016/j.jamda.2015.04.015.

44. Jiang Y-C, Feng H, Lin Y-C, Guo X-R. New strategies against drug resistance to herpes simplex virus. Int J Oral Sci. 2016;8(1):1-6.

45. Li TCM, Chan MCW, Lee N. Clinical implications of antiviral resistance in influenza. Viruses. 2015;7(9):4929-44.

46. Wiederhold N. Antifungal resistance: current trends and future strategies to combat. Infect Drug Resist. 2017; Volume 10:249-59.

47. Pakyz AL, Dwyer LL. Prevalence of Antimicrobial Use among United States Nursing Home Residents: Results from a National Survey. Infect Control Hosp Epidemiol. 2010;31(6):661-2.

48. Schechner V, Temkin E, Harbarth S, Carmeli Y, Schwaber MJ. Epidemiological interpretation of studies examining the effect of antibiotic usage on resistance. Clin Microbiol Rev. 2013;26(2):289-307.

49. Dik J-WH, Hendrix R, Poelman R, et al. Measuring the impact of antimicrobial stewardship programs. Expert Rev Anti Infect Ther [Internet]. 2016;14(6):569-75.

50. Dodds Ashley ES, Kaye KS, DePestel DD, Hermsen ED. Antimicrobial stewardship: philosophy versus practice. Clin Infect Dis. 2014;59(S3):S112-21.

51. McGowan JE. Antimicrobial Stewardship - the State of the Art in 2011 Focus on Outcome and Methods. Infect Control Hosp Epidemiol. 2012;33(04):331-7.

52. Bell BG, Schellevis F, Stobberingh E, Goossens H, Pringle M. A systematic review and meta-analysis of the effects of antibiotic consumption on antibiotic resistance. BMC Infect Dis. 2014;14(13):1-25.

53. Monnet DL. Measuring Antimicrobial Use: The Way Forward. Clin Infect Dis. 2007;44(5):671-3.

54. Neilly MDJ, Guthrie B, Santiago VH, Vadiveloo T, Donnan PT, Marwick CA. Has primary care antimicrobial use really been increasing? Comparison of changes in different prescribing measures for a complete geographic population 1995-2014. J Antimicrob Chemother. 2017;72:2921-30.

55. Polk RE, Fox C, Mahoney A, Letcavage J, MacDougall C. Measurement of Adult Antibacterial Drug Use in 130 US Hospitals: Comparison of Defined Daily Dose and Days of Therapy. Clin Infect Dis. 2007;44(5):664-70.

56. Costelleo, C., Metcalfe C, Lovering A, Mant D, Hay AD. Effect of antibiotic prescribing in primary care on antimicrobial resistance in individual patients: systematic review and meta-analysis. BMJ. 2010;340:c2096. https://doi.org/10.1136/bmj.c2096.

57. Llewelyn MJ, Darwin E, Tonkin-Crine S, et al. The antibiotic course has had its day. 
Br Dent J. 2017;223(5):337.

58. Falagas ME, Karageorgopoulos DE, Grammatikos AP, Matthaiou DK. Effectiveness and safety of short vs. long duration of antibiotic therapy for acute bacterial sinusitis: A meta-analysis of randomized trials. Br J Clin Pharmacol. 2009;67(2):161-71.

59. Dimopoulos G, Matthaiou DK, Karageorgopoulos DE, Grammatikos AP, Athanassa Z, Falagas ME. Short- versus long-course antibacterial therapy for community-acquired pneumonia: a meta-analysis. Drugs. 2008;68(13):1841-54.

60. Moehring RW, Anderson DJ, Cochran RL, Hicks LA, Srinivasan A, Ashley ESD. Expert consensus on metrics to assess the impact of patient-level antimicrobial stewardship interventions in acute-care settings. Clin Infect Dis. 2017;64(3):377-83.

61. Morris AM. Antimicrobial Stewardship Programs: Appropriate Measures and Metrics to Study their Impact. Curr Treat Options Infect Dis. 2014;6(2):101-12.

62. National Institute for Health and Care Excellence. Antimicrobial stewardship: prescribing antibiotics, Key therapeutic topic [KTT9] [Internet]. 2015.

https://www.nice.org.uk/advice/ktt9/resources/antimicrobial-stewardship-prescribingantibiotics-1632178559941. Accessed 31 Aug 2018.

63. Center for Disease Dynamics, Economics \& Policy. State of the World's Antibiotics, 2015. CDDEP: Washington, D.C.; 2015. https://www.cddep.org/wpcontent/uploads/2017/06/swa_executive_summary_edits_2016.pdf. Accessed 31 Aug 2018.

64. Williamson PR, Altman DG, Bagley H, et al. The COMET Handbook: Version 1.0. Trials. 2017;18(S3):280.

65. Williamson PR, Altman DG, Blazeby JM, et al. Developing core outcome sets for clinical trials: Issues to consider. Trials. 2012;13:132. 